\title{
Advanced Nasopharyngeal Squamous Cell Carcinoma
}

National Cancer Institute

\section{Source}

National Cancer Institute. Advanced Nasopharyngeal Squamous Cell Carcinoma. NCI

Thesaurus. Code C150207.

A squamous cell carcinoma of the nasopharynx that has spread extensively to other anatomical sites or is no longer responding to treatment. 